\title{
A Foucauldian Reading: Power in Awakening by Kate Chopin
}

\author{
Narges Raoufzadeh ${ }^{1}$, Fatemeh Sadat Basirizadeh ${ }^{2}$, Shiva Zaheri Birgani ${ }^{1,3}$ \\ ${ }^{1}$ Department of English Language and Literature, Science and Research Branch, Islamic Azad University, \\ Tehran, Iran. \\ ${ }^{2}$ Young Researchers and Elite Club, Qom Branch, Islamic Azad University, Qom, Iran \\ ${ }^{3}$ Islamic Azad University, Masjed Soleyman, Khuzestan Province, Iran \\ raufzadehn@gmail.com
}

\begin{abstract}
This paper traces Foucault's notion of power in Kate Chopin's The Awakening. The writers bring into the light, different aspects of a woman's position in the society of late nineteenthcentury America. Paper looks at private and social conditions of women, using Foucault's ideology of power, and discuss the reactions of Chopin's protagonist in relation to her actions towards the workings of power in her life. With a close analysis of the novel based on Foucault's ideology of power, researchers discuss the workings of power in the protagonist's married and social life, including her efforts to set herself free from this power and her process of resistance analyzed according to Foucault's theory. The research comes to the conclusion that the impossibility of acting outside power, the possibility of resisting power from within and Foucault's "Care of the self" as the only way to traverse the power-defined failed of possible actions. Paper shows that, Chopin's protagonist does not resist patriarchy based on Foucault's methods and her actions towards power do not lead to any effective ending.
\end{abstract}

Keywords

power; resistance;

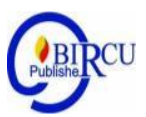

\section{Introduction}

This paper traces Foucault's notion of power in Kate Chopin's the Awakening. It looks at private and social conditions of women using, Foucault's ideology of power and discusses the reactions of Chopin's protagonist in relation to her actions towards the workings of power in her life. Foucault believes that power is not limited to one source; it can be found in all layers of society and is positive and productive. Power, he believes controls people by the process of normalization. Resistance to power therefore has to be done from inside the power structure because power is an all-embracing entity out of which nobody can act. He proposes the process of "care of the self" as a way to resistance. Chopin's protagonist tries to resist the power of patriarchy in her society and personal family life. The paper shows that her process of resistance does not fit into Foucault's definition of the term. She tries to confront power directly and from outside, and therefore her efforts do not lead to the result she wished for. She proves to be unable to live a life free from male presence; and not strong enough to live an independent life. She finally finds her freedom in death and ends her life in sea. So the paper shows that the protagonist does not succeed because she does not have enough knowledge of her social, cultural and private life which Foucault believes is the first condition for an effective resistance. 


\section{Research Methods}

\section{Foucault and Resistance}

Although Foucault believes that the subject is constituted by power, he does not reject the idea of resistance to this power. Foucault argues that resistance is not outside power, and it depends on it. In his view, resistance grows out of the power against which it struggles. Therefore, resistance is internal to power (Hartman, p.3). The resistance which he talks about does not show itself when those who are subject to power try to rise above and defeat the existing network of power structures. It happens when they deliberately challenge the expectations of those who are in the position of power. By this rebellion they refute the stability of their identity within the expected bounds, when this rebellion continues; it produces some possibilities of change and therefore effective resistance.

Foucault suggests specific and local struggles which try to loosen the constraints and provide more chances for action, so, based on what he says, if you want to resist power, you cannot confront it by trying to eradicate it or settle yourself in its place. In other words you cannot free yourself totally from the constraints of power. Resistance in the Foucauldian manner means that you should try to expand your scope of action within the framework and limitations that are defined and stated by power (Bevir, pp. 16-18). Based on Foucault's views about disciplinary power, in order to struggle against it. We should refuse what we are. The reason is that we are objects of disciplinary practices and are tied to our identities; so in order to resist this power, we must free ourselves of the limitations which are imposed on us by normalizing identity categories.

Foucault's idea that identity is constructed by power has been used by feminists to show the processes through which the normative and stereotypical forms of masculine and feminine identities are produced. What Foucault claims about identity as a power-constructed entity, does not mean that it is determined or artificial. It rather shows that our gender identities, and the way through which we act and perform these identities are defined by cultural norms. For example, natural female identity is defined as submissive, domestic, passive, etc, and by contrast a natural male identity is expressed as active, practical, rational, etc. Cultural norms produce and maintain the idea that gendered identities are natural. In this way they can conceal their roles in regulating these identities. Therefore, heterosexuality, feminine physical and moral ideas (motherhood, womanhood, etc) are considered natural and normal, and any form of deviancy from them as abnormal.

As the researchers stated about Foucault's concern with resistance, distinguishes between ethics and morality, and argues that the capacity to resist needs a type of agency which can be developed by an ethic of care of the self. There are three decisive elements for experimentation with self, an awareness of one's current condition as defined by the given culture and historical moment, and finally an attitude or disposition to critique. Foucault believes that obtaining a good knowledge of our present reality and trying to change it at the same time is a step towards self-formation. The present reality entails our cultural and social conditions, and the way we live in society. We should accept the fact that our identity, the way we are and the way we act are all the effects of power structures and are produced by them. We have to live base on those rules and norms which are set us by the disciplinary system of power. If we are clearly aware of the mechanisms of power and the way that they act on us, we will be able to cope with them in a more effective way. Accepting our real world and having a good knowledge of it keeps us from elevating our present to a state of undeniable significance or leaving it in order to find an ideal, better one. The researchers 
believe that the most important point about getting a good insight of our present reality is at the same time that we accept it. This means that although we live in present and accept its reality, we do not have to give up to it.

The second element that Foucault states as being deceive for ethical self-formation is that one should be aware of one's present condition, one's cultural circumstances, and also the historical moment. Following this element, he argues that in order to resist the modern form of power, and after you obtain the awareness, you should believe the reality of your present situation and then try to violate it at the same time. Moreover, he argues that the structures of power cannot be displaced. You cannot overthrow the existing power- relations and restore them according to your own standards and benefits. The power which Foucault discusses is not summarized in a particular source. It is present everywhere and in the context of all relations (Mills, p. 35).

That is why you cannot destroy it by dethroning the source, for example the king. Foucault also states the idea that the act of resistance to power can be done in the frame work which power itself has set for you (Bevir, pp.16-18). Therefore your scope of action vis-à-vis power is determined for you. Researchers' opinion concerning this form of resistance and its possibilities is that according to Foucault's definition, your resistance will be eventually set by power. Although you can choose the kind of your actions and efforts within the powerdefined structure. You are still bound with the rules and standards of the same power. Therefore, you should play according to the game rules, even if you have found new methods to play the game. Here the paper will discuss these elements in the case of Edna and the process through which she tried to resist the normalizing power of her society.

III. Discussion

\section{Edna and Resistance to Power}

Edna lives in a society that encompasses traditional and patriarchal patterns in their most restricting sense. The Creole community in which she dwells is a male-centered one in which the norms have described the female as the one who is dependent on the male, and is domestic and emotional. She should be "an angel in the house" taking care of her children and her husband. The female model of perfection is the sacrificial mother-woman who effaces herself for her family's welfare. On the other hand, the male figure is described as independent and traditional. He should be in control of his family and especially his wife. He bears the responsibility of economic matters of his family. While his wife control the domestic affairs, he is responsible for social matters. Edna is surrounded by controlling men and mostly conventional women. In such a society, Edna's efforts to become independent from her husband and male dominance meant a great opposition and threat to the dominating social and cultural structures.

For her husband she is a possession, something that belongs to him. A Creole wife was considered her husband's possession and had the same role as his other belongings such as house. Her appearance and behavior in society were as decisive in her husband's social status as the kind of job or his living place. One can say that a Creole woman's role is actually like a glass through which her husband is judged. Edna's form of resistance is not of the kind that Foucault argues. She does not resist within the structure of power. Her actions are of the rebellious kind. Since her first stages of awakening. When she was becoming aware of her different feelings and ideas, all she did was nothing but transgression. None of her actions were performed in the defined cultural and social frameworks. She rejected all codes of value 
which ruled the Victorian mind of her time. She was not a mother-woman, or a sacrificial wife.

Her feminine features were being replaced by behaviors which were defined as more masculine. Her self-assertiveness, and acting as a sensuous active agent in sexual affairs were taking her far from standards of femininity. She did not care about her domestic household affairs or her husband's social condition. Her mind was haunted with ideas of independence and freedom from marital bounds. Passing time with Robert or with socially unacceptable men like Alece was becoming more enjoyable and important in her daily schedule, than attending family gatherings and acting the role of a domestic, ideal wife. Her efforts to become an artist were not aimed at delighting her family and guests, but at self-expression. She does not play for her family, and starts painting and selling her art works. In this way, everything that she does for setting herself free from power structures of her society is nothing but rejecting them directly.

The second element of Foucault' formula of resistance cannot be seen in case of Edna. She does not try to get a good understanding of her present. Her actions clearly show the fact that she is following her instincts and emotions. Her behavior is rash and not thoughtful. If she had reached a full understanding of her cultural and social realities, she would not have acted so impulsively. By Considering the norms which dominated her society she can easily conceive this reality that transgressing these rules ends in a life like that of Mademoiselle Reisz. Actually she does not have a clear definition of her aim, and does not even know herself well. If she had a better understanding of how an independent life would be, she would not replace her dependence on her husband with her dependence on another male figure like Robert. She just wants to get rid of the bounds and restrictions which life has placed on her, but she cannot find the appropriate means.

She also does not have a good awareness of her capabilities for living a life of her own.She cannot bear seclusion and loneliness. In order to fill the gap of a passionate relationship in her marital life. She goes to Robert and his love, and later when Robert leaves for Mexico, she tries to fill his gap with a sexual affair with Alece Arobin, despite the fact that she does not have any feeling towards him. This shows her weakness and the fact that she cannot live an independent life, because she does not have emotional independence. Based on these personal attributes, Edna cannot enter the scope of the third element of Foucault. At this stage Foucault says you must accept your present reality and your being a purposeful agent both at the same time revolt against it. Edna does not admit her reality as a woman of the Victorian society. She does not understand her reality as a mother who has two children, and like it or not has some sort of responsibility towards them. If she had accepted her reality she may not have committed suicide as a way to escape.

Although Edna does not seem to be strong enough for revolt, the researcher believes that her social and cultural positions do not give her proper space for that. The researcher's opinion is that although Foucault's attitude is a hopeful one, it can not be brought into action without paying the price. When one lives in a normalized society and is produced by its norms, acting against one's normalized identity or in other words rejecting what one is, will place one in a state of exclusion. By rejecting one's identity one can define oneself as abnormal and is consequently lead to seclusion. This condition is best portrayed by Chopin in chapter of Mademoiselle Reisz. She is not welcomed in social gatherings and lives a secluded life, because she doesn't fit into the standard female definition of the 19th century. Chopin shows the reader that if Edna wants to live a life of her own, she will have a condition like 
that of Mademoiselle Reisz. This older woman stands as the model of independence for Edna, but this quality is very unacceptable in her culture and society.

As a regional work of fiction, The Awakening realistically pictures the life, culture, customs and values of Creoles. The language, landscape and names of places are realistically presented, and many of their customs such as their gatherings, free time activities, family structures and relationships are clearly depicted. The novel can also be considered a new woman work because it discusses women rights, their position in marriage and their role within their family and society. Its protagonist resists the dominant norms of proper femininity. In contrast to these norms, she is portrayed as self-assertive, sensational, and independence seeking. Actually this novel along with other new woman works of fiction were trying to make clear the workings of patriarchal power in ordering females to its own benefit by attributing to women qualities such as being spiritual and saintly and therefore keeping them in the domestic realm of the house as a part of men's possessions.

\section{Conclusions}

According to what has been discussed, although the protagonist of Chopin's novel tries her best to challenge and resist the prevailing norms of her society, the power structures does not give way into any transgression and silences her at the end she defies nearly all the traditional notions of normal, proper femininity, like motherhood, wifehood, and acceptable womanhood. She even dares to leave her family house and live in a house that is on her own property. She is brave enough to seek sexual partners and act as an active sexual agent. Looking at her actions in the light of Foucault's theories of care of the self and possibilities of resistance makes this point clear that the modern form of power does not give way to any type of replacement. According to Foucault, the only way to resist power is to expand one's scope of action in the frame work that power has defined (Bevir, pp. 16-18). Therefore one can never obtain total freedom from the constraints of power. As mentioned earlier, Foucault also mentions three elements for ethical self-formation and resistance to power (Infinito, $\mathrm{p}$. 14).

Edna does not fit into any of these circumstances. Her space of action is not a suitable one for helping her to modify the situation. She lacks the required awareness of the present, and her cultural and social realities, and this is why she cannot change anything. She does not believe her reality and just tries to transgress the borders. In order to change anything, one must have enough understanding and knowledge about it. Edna closes her eyes to her society's values and her situation in that society and tries to force her own principles. Apart from lack of proper circumstances, Edna is not strong enough to bear a lonely life. She still needs to be related with a man, and although she challenges many traditions concerning the structure of family and the institution of marriage, she cannot stand a life devoid of passion. In order to resist, she gradually acquires male attributes. She tries to fight patriarchy by becoming like a man in appearance as well as behavior. This is actually a failure, because she cannot struggle as a woman and is formed by male values of independence. Concerning the possible choices of Edna, other than suicide, researchers believe that regarding Edna's state of awareness and her new born world view there is actually no choice that can satisfy her awakened soul. Although her suicide may seem to be an escape, it is to be expected and the only possible way for her to attain peace and comfort.

As a rebellious novel, The Awakening by Kate Chopin has been considered as an exploration into the conditions of women during the late 19th. It records a woman's hopeless 
struggles to break through the cultural bounds and restrictions of her society. The patriarchal system was so deeply rooted in her society and people around her that, her efforts in order to live based on her inner desires, awakened self and also her resisting the prescribed feminine roles turned out to be useless, and finally resulted in her decision to leave that life. Because of the portrayal of a woman's challenging traditional female roles of motherhood and womanhood this novel has also been discussed as a feminist work. So the novel is a brave one because it dares to portray those aspects of a feminine self that were considered taboo, at the time of its publication. It is also considered a French Creoles who were living in Louisiana at the time of the novel. The characters of Chopin's novel can be easily described according to the social norms and expectations of her traditional, male-centered society.

Chopin portrays her process of awakening to the realities of her society as well as that of her being. As an example of a new woman figure, she ignores her role as a dutiful wife and self-sacrificial mother. She lacks almost all the standards of "the angel in house" notion, and her appearance as well as behavior challenges the Victorian ideals. Her resistance and her ending in the novel are both good examples of the working of power, especially the power of patriarchal norms, in her life. Edna is the prototype of any young woman who becomes aware of the injustices of her society and her own sexuality. She rebels against the patriarchal restrictions and attempts to realize her inner self. The novel depicts the fact that not all women can take themselves out of this traditional structure. Even though many of them try their best, they cannot obtain satisfactory results. Edna feels a need to break away from the bounds of motherhood, wifehood, and restrictive roles of womanhood. She knows that she is different from many women.

Paper discusses the way through which patriarchal power functions in the society of Chopin's time, and also the novel's protagonist in terms of her resistance to the prevailing power of the Victorian patriarchy and social norms. By making a contrast between her protagonist and two other women in the story, Chopin clarifies her protagonist's personality. She is compared with a model of pure traditional woman who is the embodiment of all proper feminine qualities and also with an independent, unmarried woman. This comparison shows the reader that the protagonist is neither of these two. She is trying to turn from the first and reach the second, but actually she is not able to lead a life of independence. Although she resists the marriage institution, prefers her interests and desires to those of her family, and ignores the expectations of society from her as a wife and mother, she does not have enough strength and stability to bear the loneliness of living as an independent life.

Depicting an independent woman as living in a state of solitude and seclusion, Chopin shows the protagonist's status in society if she chooses to live on her own. Society of her time does not accept woman's independence and their transgression from norms of femininity. The Protagonist of the novel is trying to resist the prevailing power of patriarchy in her society by challenging standards of femininity. Her process of resistance is not in accordance with Foucault's theories of resistance. He defines resistance to modern forms of power in terms of "Care of the self" for which he proposes three elements. Chopin's protagonist does not fit in any of them. She does not have a safe and experimental space to practice selfformation in its Foucauldian sense. Her society is a pure traditional one in which any form of transgression is unacceptable and is punished by putting the transgressor in a state of ignorance and exclusion. She is circled by possessive men and the limitation of marriage. She does not have a deep understanding of her present reality.

She does not regard her situation as the wife of a Creole man who has two children. Her not accepting the reality, leads her to cross the borders and make a fruitless effort towards 
living beyond the limits. Although she may have the courage to resist she does not have enough insight. According to Foucault, resisting disciplinary power is eventually determined by the power itself. One cannot resist power from outside and impose one's will on it. Resistance can only be performed from within and in the power-defined structure. That is why Chopin's heroine cannot perform a successful Foucauldian resistance. The researchers argue that the protagonist of Chopin's novel is not strong enough to live an independent life. Traditional rules are not strong enough to live an independent life. Traditional rules are so deeply rooted in her mind that she is unable to completely free herself from male dominance. Although she revolts against the institution of marriage, she cannot obtain emotional independence and falls into a romantic relationship, she argues that she will not let any other man possess her, but she is actually possessed by a strong attachment to a male presence.

Her mind is haunted by her lover and she even fills his gap by turning to another man whom she does not love. She gradually acquires the male attributes in the course of her resistance. She cannot struggle as a woman, and instead fights patriarchy by becoming like a man. Her rash behavior leads to her disappointment and committing suicide. Although her final act may seem to be an escape, the paper argues that no other choice seems to be possible for her to reach peace and comfort. Researchers believe that according to Foucault's ideology, although you can resist, your scope of action is defined by the very power that you try to resist. Therefore, although one can find new ways to play the game, he should play according to the game rules. Chopin's novel is a good example of what happens to a woman who decides to transgress her society's bounds. Her form of resistance is a direct one which aims at ignoring the rules with the hope of being understood. She rejects all the codes of true womanhood which her Creole society has established. Her method of resistance does not fit into Foucault's model. Her understanding of the power of patriarchy is a totally restrictive one summarized in the constitution of marriage. In order to resist this power and live for her inner self, she tries to draw herself out of the limitations of her married life. She ignores her children, passes most of her time walking around with her lover, and stops submitting to her husband's desires.

Her environment is not a safe one that can provide her with suitable situation to act. She lives in a community in which people are deeply traditional and no revolutionary and unconventional behavior is acceptable. Furthermore she does not resist as a married woman with two children. According to Foucault, she should be aware of her current condition as defined by the given culture and historical moment (Infinito, p.14). Chopin's heroine should analyze her situation as a woman living in the Creole society of the late 19th and take action based on an all encompassing consideration of circumstance. In contrast to this, she tries to live an independent life similar to that of Mademoiselle Reisz. Foucault argues that in order to violate our present reality we should be able to accept and respect it first. The protagonist of The Awakening directly violates all rules and norms of her culture and time without taking a logical consideration of the circumstances. Considering the protagonist's resisting actions in the light of Foucault's theories of "Care of the self" and possibilities of effective resistance clarifies the point that the modern form of power 


\section{References}

Barry, Norman P. (1989). An introduction to Modern Political Theory.2nd ed. London: Macmillan Education Ltd.

Bevir, Mark: "Foucault and Critique" University of California Postprints, 1999. http: "repositories, cdlib,org/cgi/view content.

Chopin, Kate.( 1988). The Awakening and Selected Stories. Gilbert, Sandra M, Harmonds Worth: Penguin Classics.

Cirlot, J.E.A.(1962). Dictionary of Symbols. Trans, Jack Sage. New York: Philosophical Library.

During, Simon. (1992). Foucault and literature: Towards a Geneology of Writing. London and New York: Routledge Publication.

"Edna Pontellier \& Social Limitations in Kate Chopin's Awakening" http://www.azete.com/preview.Foucault, Michele. (1975). Discipline and Punish: The Birth of the Prison. Trans. A.M. Sheriden. London: Penguin.

Ellis, Judy and Jean Johnson. Changing Women's Significance through Literature in the late 19th. 2003 http://en.wikipedia.org/wiki/kate-chopin www.iep.utm.edu/f/foucfem.htm

Gaeini \& Basirizadeh. The Role of Language and its Analysis in James Joyce`s Dubliners within the Light of Cultural Materialism. 2019. Budapest International Research in Linguistics and Education Sciences (BirLE) Journal, 16-26.

Martin, L.H. etal. (1988). Technologies of the self: A Seminar with Michel Foucault. London: Tavistock.

Mills, Sara. (2003). Michel Foucault. London: Routledge.

Pykett, Lyn.(1992). The Improper Feminine. London: Routledge.

Rabinow, Paul. (1984). The Foucault Reader: An Introduction of Foucault's Thought. London: Penguin Books.

Regan Stephen. (2001) The Nineteenth- Century Novel. New York: Routledge.

Russel, Bertrand. (1938). Power: A New School Analysis. London: Allen and Unwin.

Selden, Raman and Peter Widdowson. (1993). A Reader's Guide to Contemporary Literary Theories. London: Harwester Wheat Sheaf.

Smart, Barry. (1988). Micheal Foucault. London: Routledge.

Toth, Emily. (1999). Unveiling Kate Chopin. Mississipi University Press: Jackson.

Walker, Nancy A.(2001). Kate Chopin, A Literary Life. New York. Palgrave. 